\title{
THE RIGHT OF STOCKHOLDERS TO NEW STOCK
}

Text-book writers and many courts unite in the assertion that the stockholders of a corporation have each an individual and indefeasible right apart from legislative action to subscribe for any new issue of stock in proportion to their respective holdings. The doctrine is thus stated in Cook on Corporations." "When the capital stock of a corporation is increased by the issue of new stock, each holder of the original stock has a right to offer to subscribe for and to demand from the corporation such a proportion of the new stock as the number of shares already owned by him bears to the whole amount of shares before the increase. This pre-emptive right of the stockholder in respect to new stock is well recognized." The reason which is given for the existence of the doctrine is that "Any other rule would enable the parties in control to seize the new stock, in some cases for gain, because the stock is worth more than par, and in other cases so as to acquire increased votes at a coming election. In either case this would work a fraud on the other stockholders." 2 It may be added that the right, as it is defined to-day, seems to be in the nature of an option, as there is no correlative duty upon any shareholder to take his proportion unless he cares to do so.

The privilege has been granted definitely by statute in many jurisdictions but the question arises from time to time in States where no such action has been taken and the principle is asserted without hesitation. Indeed, any discussion of the propriety of the doctrine seems rather academic at this time, but it may be of interest to consider the matter briefly as an illustration of "judge made law," and inquire how far logic and policy requize the course.

In the first place, the explanation given in the passage quoted certainly is an unusual extension of the remedies established for one who is injured by the fraud of others. These are negative, enabling one to avoid an obligation or to enjoin possibly an

\footnotetext{
${ }^{1}$ Fifth Ed. § 286. For similar statements, see II Beach on Private Corporations, $\S 473$, and Thompson's Commentaries on Corporations, $\S 2094$.

2 Cook, § 70.
} 
undertaking proposed by those accused. But to grant a person an exclusive and affirmative right to which he would not be entitled otherwise because the original possessors might employ it to his detriment, seems much like winning a case upon the weakness of the defence alone. Moreover, if "any other rule" would permit a majority of the stockholders to get the new stock, does the doctrine anounced really prevent such a "fraud?" They would still be entitled to a proportionate majority of the new. And without the assistance of the rule, an attempt by those in control to perpetrate a fraud upon the minority could be prevented by the proper tribunal.

The great stream of decisions and approving comments on this right flow from a Massachusetts case, decided in 1807, as the fountain. Gray v. Portland Bank, ${ }^{3}$ was recently referred to by the Court of Appeals of New York as having "stood unquestioned for nearly a hundred years," and as being "the foundation of the rule upon the subject that prevails, almost without exception, throughout the entire country."

It will be of interest then to examine that case briefly and see how far it may be cited as an authority for the doctrine that now obtains. The circumstances were that a bank had been organized with a capital "of a sum not less than $\$ 100,000.00$ nor more than $\$ 300,000.00$." After all the subscriptions for the $\$ 100,000.00$ with which they began were in, the plaintiff was admitted as subscriber for seventy shares and the bank was then incorporated. In a few years the shareholders voted at a meeting to issue the two thousand unsubscribed shares, offering them to the original subscribers, their associates previous to the act of incorporation and to the assignees of such original associates. Plaintiff tendered his subscription for one hundred and forty shares and was refused for a reason which is not clearly given, whereupon he brought an action at law for damages. The Court held that this was not an issue of new stock but "an addition of the bank already commenced." "A vote to increase the capital stock, if it was not the creation of a new and disjointed capital, was in its nature an agreement among the stockholders to enlarge their shares, in amount or in number to the extent required to effect that increase. The shares first paid in became the first instalment of the increased capital; and the subsequent payments might be

${ }^{8} 3$ Mass., 364 .

4 Per Vann J., I86 N. Y., pp. 29I and 292. 
reasonably enforced, by providing for a forfeiture of delinquent shares, to be sold and accounted for to the stockholder: the proceeds to be carried to his account, deducting the instalments or additional payments required."

The essential points in this case, which appear in the passages quoted and which render it inapplicable as a precedent for any one-sided doctrine such as that now asserted are: (a) The Court express!y adopted the theory that, by reason of the maximum capitalization which had been named in the charter but which had not been utilized theretofore, the new issue was not an addition of "disjointed" capital but an enlargement of each stockholder's share by agreement. This, the Court said, might have been done by trebling the par value of each share or by increasing the number of shares as was actually done. (b) The other and vital divergence resides in the explicit assertion of the Massachusetts Court that payment for the new stock might be enforced against a stockholder. There is the whole matter in one sentence. The Court simply said that the stockholders had agreed to enlarge their interests and were not only privileged to take their several proportions of the new stock, but might be compelled to do so.

Even assuming that the Portland Bank case is a precedent for the doctrine announced to-day, there are some considerations which diminish its authority as a leading case: (a) It was decided in 1807 when corporate conceptions were far more dim than they are at present, as may be gathered, for instance, from the old phraseology still preserved in statutes, permitting persons "to become a corporation," whereas to-day we almost uniformly speak and think of "organizing a corporation." The absence of a direct claim of the stockholder upon the corporate assets has been emphasized rather than weakened. (b) Of the five Judges constituting the Court, two (including the Chief Justice) took no part in the case through interest, while a third merely said verbally, that he thought the plaintiff should be allowed to recover, but assigned no reason and did not suggest any rule as to the measure of damages. (c) The Massachusetts Legislature many years later adopted a statute, specifically granting this right to stockholders, which would seem to indicate that they did not regard the case as establishing the law for all time in that Commonwealth.

Rev. Statutes of Mass. (1901), Ch. ז10, $\S 34$. 
In order to observe in the first place how the doctrine has changed and devoloped under judicial decisions in spite of the retention of the Gray case as the chief authority, and in the second the embarrassment which Courts find in giving a clear reason for their attitude, a late decision in a leading jurisdiction may be referred to briefly.

The question was recently before the New York Court of Appeals ${ }^{6}$ and in a carefully considered opinion that tribunal affirmed without dissent, the existence in the State of the following doctrine, after premising that the statutes were silent and that the question was a new one as far as that Court was concerned. "We are thus led," said the Court, "to lay down the rule that a stockholder has an inherent right to a proportionate share of new stock issued for money only and not to purchase property for the purposes of the corporation or to effect a consolidation, and while he can waive that right, he cannot be deprived of it without his consent except when the stock is issued at a fixed price not less than par and he is given the right to take at that price in proportion to his holding, or in some other equitable way that will enable him to protect his interest by acting on his own judgment and using his own resources."

The facts in the case were briefly as follows: The plaintiff, $S$, was an original stockholder in the defendant company, which, in January, 1902, decided to double its capital stock, then having a book value of about $\$ 300.00$ a share. $B$, a prominent banking house in New York, made a written offer to take all of the new stock at $\$ 450.00$ a share, provided the stockholders authorized the issue. This was done at a meeting of stockholders by the vote of those owning a majority, $\mathrm{S}$ voting for the increase. $\mathrm{He}$ then demanded that he be allowed to subscribe for his pro rata share of the increase at par, which was refused. He protested and voted against the sale to $B$ which, however, was approved by a very great majority, when he renewed his demand for his proportion and was again refused. Owing in part to the offer of $B$, the market value had increased from $\$ 450.00$ to $\$ 550.00$ per share in January, I902, and at the time of the trial was $\$ 700$. Before the meeting of the stockholders, a circular letter had been sent advising all, including $S$, of B's offer, and $S$ had notified the defendant that he wished to subscribe for his proportionate share, if issued, and had been informed that his proposition would be

${ }^{6}$ Stokes v. Continental Trust Company, 186 N. Y. 285 (1906). 
taken under consideration. The Trial Court gave judgment for $S$ for the difference between the market value when the stockholders met and the par value. The Appellate Division ${ }^{7}$ reversed this decision upon the express ground that $S$ had-offered only par instead of the figure of B's offer, observing that each stockholder has a "pre-emptive right as against an outsider to subscribe for this stock at the price at which it is issued by the corporation." The Court failed to find any reason for the rule but suggested that it was "Iargely due" to the justice of maintaining a stockholder's proportionate interest in the corporate assets unreduced, adding that the matter is of so much importance that many States have adopted statutes preserving it. The Court of Appeals reversed the judgment of the Appellate Division and affirmed that of the Trial Court, modifying it so as to make the measure of damages the difference between the market value and the price at which $B$ had agreed to take the new stock.

A distinction between the facts in this and in the Gray case appears at once. The older, as mentioned above, dwelt upon the fact that the greater capitalization had been provided for in the charter and was not "the addition of disjointed capital." This seems to have been a vital point in earlier days. Thus in Angell \& Ames on Corporations, a work originally published in $183 \mathrm{I}$, it is said :8 "If a corporation, in other words, is created with the privilege of raising a stock not less than one sum, nor exceeding a certain greater sum, and commence business with the smaller capital and it is afterwards decided by a vote to augment it to the greater, an original subscriber has, as a stockholder, a right to subscribe for and hold the new stock in proportion to his interest in the old stock." In the Stokes case the increase was apparently "new and disjointed," inasmuch as the action does not seem to have been by virtue of any provision in the original certificate of incorporation. In other words, where in a charter a minimum and maximum capitalization are expressly provided for, it might well be held that the right to take the increase was part of the consideration for the shareholders' subscriptions in the first place. But where the addition is due wholly to a later act of the body of stockholders, this reason does not apply.

The Courts purport, in arriving at their conclusions on this subject, to follow logic as well as authority. It having been

\footnotetext{
${ }^{7} 99$ App. Div. (N. Y.) 377.

8 \&554.
} 
pointed out that the second basis is extremely weak in this instance, the arguments employed to show how necessary and proper the cloctrine is, may be examined.

It may be said here in passing on the question of following atthority that the cases are not wholly agreed as appears from some of those cited in the opinion under discussion. Thus one, an early New York decision ${ }^{\circ}$ in a dictum as carefully considered as the essentials of the opinion, declared that a stockholder had "no more right to a distributive share of any stock of the corporation belonging to itself than to any other property belonging to it. Prima facic, all the property of the corporation was dedicated to its use for the purpose of advancing the enterprise for which it was organized; and any stock it might own whether of its own capital or that of any other company, like any other property, was to be used in the discretion of its officers to accomplish that and in the manner most beneficial to the corporation and corporators as such." Another, although turning upon the interpretation of a charter, questioned the authority of the "leading case," saying: "10 "Whether Gray v. Portland Bank was rightly decided on its own facts we shall not inquire: but the decision in it, we have no hesitation in saying, cannot be applied as a general rule of law to all stock corporations." While in a third it was said:11 "In general, the present holders of stock have a primary right to.subscribe in proportion to their holdings for any new issue. The stockholders themselves may determine otherisise and order a sale to the public and payment of the proccids into the treasury. But this is exceptional and the exercise of a reserve power which should not be permitted unless there is a clear intent of the stockholders to do so."

After citing and commenting upon the authorities, the Court in the Stokes case observed that if the right asserted by the plaintiff were a property right, he could not be deprived of it by any action of the other stockholders and proceeded to consider the nature of his relations to the corporation.

"A corporation," runs the opinion, "is somewhat like a partnership if one were possible, conducted wholly by agents where the co-partners have power to appoint the agents but are not responsible for their acts. The power to manage its affairs resides in

9 Miller v. Ill. Cent. R. R. Co., 24 Barbour (N. Y.) 313.

10 Ohio Insurance Co. v. Nunncmacher, 15 Ind., 294.

${ }^{11}$ Morris v. Stevens, 178 Pa. State, p. 578. 
the directors, who are its agents, but the power to elect directors resides in the stockholders. This right to vote for directors and upon propositions to increase the stock or mortgage the assets is about all the power the stockholder has. $* *$ Hence the power of the individual stockholder to vote in proportion to the number of his shares is vital and cannot be cut off or curtailcd by the action of all the other stockholders even with the co-opcration of the directors and officers."

Here the theory clearly is that each stockholder is entitled, if he wish, to maintain his original proportion of the stock outstanding. Yet further down it is said: "Of course there. is a distinction when the new stock is issued in payment for property, but that is not this case. ** When the new stock was issued in payment for property purchased by the corporation, the stockholders' right is merged in the purchase and they have an advantage in the increase of the property of the corporation in proportion to the increase of stock." But what earthly difference can it make, so far as maintaining the voting proportion is concerned, whether the stock is paid for in money or property? If the action of the majority of the stockholders cannot deprive one of his privileges in the first instance, by what rule of logic may they in the other? The Court says that the corporation is enriched by the new property in proportion to the new stock. In a sale for money, is it not equally enriched by the amount received? The Court does not adopt the very obvious and simple reason. for the difference of treatment that when stock is issued for money the rule may be applied, whereas it would be impossible to do so when specified property owned by some one other than the stockholders as a body was to be received in payment. The very statement, however, of this distinction would cut the ground from under the argument about the absolute right to maintain one's proportionate interest and so the remarks about "enriching" the corporation had to be made. Again previously the Court had declared: "The issue of new stock and the sale thereof to Blair and Company, was not only a transfer to them of one-half the voting power of the old stockholders but also of an equitable right to one-half of the surplus which belonged to them. In other words, it was a partial division of the property of the old stockholders." But stockholders who had become so by selling property to the corporation and receiving the shares in exchange could vote and would also share in whatever had 
been accumulated previously and so would be taking the property of the shareholders just as surely. Moreover, in this instance, since the surplus before the increase amounted to only $\$ 209.00$ per share according to the books of the Company, and Blair \& Company were to pay for every share of their stock a premium of $\$ 350.00$, it would seem that the old stockholders' surplus fund would be increased by about $\$ 70.00$ a share instead of being deprived of anything. It may be added, that in many jurisdictions stock may be issued for labor or services rendered as well as for specific property. How would the Court regard this? No tangible value would be added to the corporation in which to "merge" the older stockholders' rights even though one might concede that the company would be in a better position than if the services had not been rendered.

Again it is said: "The new stock belonged to the stockholders as an inherent right by virtue of their being stockholders, to be shared in proportion upon paying its par value or the value per share fixed by vote of a majority of the stockholders or ascertained by a sale at public auction. While the corporation could not compel the plaintiff to take new shares at any price, since they were issued for money and not for property, it could not law fully dispose of those shares without giving him a chance to get his proportion at the same price that outsiders got theirs. * * Otherwise, the majority could deprive the minority of their proportionate power in the election of directors and of their proportionate right to share in the surplus, each of which is an inherent, preemptive and vested right of property."

Perhaps the most obvious feature of this declaration is the strange logic which it displays. The learned Judge apparently realized that to declare directly that the shareholders had merely an option upon the new stock would be wholly arbitrary and unjustifiable in the Court. By the common law, either the old stockholders owned it, as issued, absolutely, or the corporation did. In order to uphold the conclusion at which he had arrived, the former alternative was chosen. But if they so owned it "by virtue of being stockholders," why should they be obliged to pay anything for it? The proposition that people must pay for what is theirs automatically because of their position is a novel one. Upon the other hand, if it is theirs, but subject to a lien for the subscription price, why might they not be compelled to take up their own property? Assume, for example, that the Company 
became insolvent just after taking the necessary steps to issue the new stock. Would not every rule of logic and equity under the circumstances alleged by the Court to exist, permit creditors to force them to "take it up" and to pay some substantial amount, if not the full par value, into the treasury?

Moreover, if the privilege be "an inherent, pre-emptive and vested right of property" why should the majority be permitted to establish the price that should be paid? Cook says ${ }^{22}$ that each stockholder may demand his proportion at par, a rule still adhered to in some jurisdictions. Thus in Hammond $v$. Edison, ${ }^{13}$ it is said: "The right to subscribe for any increase of stock at par if he desire to do so, or to sell that right if he does not desire to exercise it himself, is one of the rights acquired by the stockholder when he becomes a subscriber to the stock," but this Court says he must pay what the other stockholders think is reasonable. Now the only measure of the value of a share of stock is the amount that would be distributable upon it in case the corporation were to be dissolved forthwith - in other words, the "book value." If the stockholder has an inherent title to the new shares, what right have his fellows to withhold his property from him unless he pay an arbitrary amount far above the intrinsic worth-forcing him to turn into the corporation the profit he might have realized had he been obliged to pay only what the shares represented in distributable assets? Is this reasonable? Is not withholding property unless a price be paid greater than its inherent worth and based upon the artificial value in open market of something else (i. e., the old stock) very much like taking it without due process of law?

It is believed that the foregoing paragraphs summarize the only arguments advanced by the Court in support of its position and the conclusion seems to be that there is in reality no logical basis for the doctrine. Indeed, the substance of the opinion is contained in the concluding remark that "this rule is just to all and tends to prevent the tyranny of majorities which needs restraint, as well as virtual attempts to blackmail by small minorities which should be prevented."

Assuming the rule to be just, is not such a declaration the assumption of legislative functions by the Court? The right as announced does not flow logically from the relation between the

$12 \S 286$.

18 I3I Mich., 79. 
stockholder and corporation. That appears from the weakness of the arguments which either contradict one another or prove too much. Indeed, the cases are filled with loose reasoning on the subject. Thus in Jones v. Railroad, ${ }^{14}$ it is said: "The Concord stockholders were the Concord Company. The Montreal stockholders were the Montreal Company. The union of the companies was a union of the stockholders. The property of each of the uniting companies belonged to its members. The circumstance that they are an incorporated trustee holding the legal title is immaterial." Another case ${ }^{15}$ described the stockholders as being like "tenants in common." Observing that if these remarks are correct it is singular that all stockholders uniting could not convey a dollar's worth of the corporate property, attention may be called once more to the New York Court's truthful remark that about the only right a stockholder has is that of voting, which does not seem to indicate very complete ownership.

In view of the widespread discussion of the matter in various jurisdictions, it must be assumed that State Legislatures are not ignorant of its existence and would regulate it by statute if it appeared advisable to do so. What power then has any Court to grant substantial rights that the Legislature has not seen fit to bestow? And is the rule just? While the objecting stockholder might be willing to pay for his small proportion a price greater than that offered by some one or more outside interests for the entire amount, neither he nor the corporation could compel the other holders to do the same, and it is very probable that a banking house would assume the attitude of "all or none," resulting in a positive loss to the corporation. In other words, one holder of ten shares of stock might, in entirely good faith, prevent the consummation of a transaction to which the holders of four thousand, nine hundred and ninety shares assented heartily. And yet he would be under no obligation to assist the corporation in finding purchasers for the remainder of the new issue. It seems as though such matters could be left with safety to the body of stockholders to determine, leaving the Courts the power now clearly possessed to forbid any issue which one shareholder might show would be an injury to him.

At the risk of repetition, the conclusion may be drawn as follows: To hold, as was done in Gray v. Portland Bank, that if a

1467 N. H., IIg, p. I3I.

${ }^{15}$ Reese v. Bk. of Montgomery, $26 \mathrm{~Pa}$. St., 143. 
charter provides for a certain increase of capital and the shareholders vote to make such increase, it is an agreement upon the part of each one to enlarge his investment by a proportionate amount of the added stock and upon his failure to take up his allotment, it could be sold for his account, is logical and comprehensible. To retain the privilege while removing the correlative obligation, and extending the application to a case where the issue of the new stock is not provided for in the charter but is an entirely new act by the body of stockholders at the timefinally to say that the majority may establish the price which a stockholder must pay, although they cannot do anything else:these seem to be quite illogical and arbitrary.

Frederick Dwight. 